\title{
Disability-inclusive employment, cancer survivorship, and the Americans with Disabilities Act
}

\author{
Peter Blanck ${ }^{1}[0$
}

Received: 12 November 2021 / Accepted: 15 November 2021 / Published online: 2 February 2022

(c) The Author(s), under exclusive licence to Springer Science+Business Media, LLC, part of Springer Nature 2021

\begin{abstract}
Purpose This special section of the Journal of Cancer Survivorship examines disability-inclusive employment policy and practice, cancer survivorship, and the Americans with Disabilities Act ("ADA") of 1990. It considers current issues in research, policy, practice, and law in the United States, including new questions arising in light of COVID-19, such as the nature of disability disclosure, workplace accommodations and remote work, emerging workplace health surveillance technologies, and inclusive employment practices for cancer survivors. It also presents, for comparative purposes, a current analysis of cancer-related disability discrimination in the media in the United States and Israel.

Methods After the "Introduction," this special section presents two studies on disclosure of disability in employment: the first addressing disclosure during a job interview of the need for accommodations, and the second addressing disclosure as related to individual and organizational characteristics. The next two articles examine the effects of the COVID-19 pandemic on the work experience: first, for people with disabilities working remotely, with implications for cancer survivors, and second, for cancer survivors and people with disabilities facing potential algorithmic health discrimination due to workplace health surveillance. The final article considers cancer-related stigma and discrimination, as faced in the United States and Israel (using a comparison of mass media).

Results Disability-inclusive employment laws such as the ADA promote two central requirements: First, social institutions affirmatively remove attitudinal and structural barriers and discrimination confronting people with disabilities as they exercise their rights to participate fully in society. Second, employers, governmental entities, and public accommodations comply with the "accommodation principle," which requires them to make reasonable adjustments to job tasks, places of work, and public places in society, to enable equal participation by qualified individuals with disabilities. The articles in this special section consider these principles in innovative ways from a disability-inclusive paradigm.

Conclusions The COVID-19 pandemic has highlighted the need for a robust research literature on disability-inclusive employment policy and practice for people with disabilities and for cancer survivors. This special section offers five articles as a start. The section's "Introduction" also highlights recent ADA case law and introduces two new national Rehabilitation Research and Training Centers, one on Disability Inclusive Employment Policy ("DIEP RRTC") and one on Employer Practices Leading to Successful Employment Outcomes Among People with Disabilities ("Employer Practices RRTC"), both designed to help fill this need. The centers are currently examining ways organizations, including those in the gig economy, can facilitate inclusive employment of people with disabilities.

Implications for Cancer Survivors As highlighted in the Introduction's discussion of recent ADA cases involving cancerrelated employment discrimination, as well as in the special section's articles, discrimination in employment persists and, indeed, is worsening for cancer survivors and those with disabilities. This discrimination affects people across the demographic spectrum, and it can be especially harmful to people in groups not always acknowledged, such as individuals with multiple, intersectional minority identities associated with race, ethnicity, sexual orientation, and gender identity, as well as people at different stages of the life course. Furthermore, the impact of discrimination in employment is often exacerbated by life experiences such as unemployment and underemployment, financial insecurity, ableism, racism, and sexism.
\end{abstract}

Keywords Cancer $\cdot$ Disability employment $\cdot$ Discrimination $\cdot$ Invisible disabilities $\cdot$ COVID-19 $\cdot$ Accommodations

Extended author information available on the last page of the article 


\section{Introduction}

Disability antidiscrimination laws, prominently the Americans with Disabilities Act of 1990 as amended by the ADA Amendments Act of 2008 (the "ADA"), promote two central requirements. First, social institutions affirmatively remove attitudinal and structural barriers and discrimination confronting people with disabilities as they exercise their rights to particulate fully in society, including in employment [1-4]. Second, employers, governmental entities, and private entities open to the public comply with the "accommodation principle," which requires them to make reasonable adjustments to places of work and services to enable equal participation by qualified individuals with disabilities [2, 5-13]. Disability-inclusive employment for people with disabilities is grounded in these basic requirements.

Disability-inclusive employment policy and practices have been complicated today by the COVID-19 pandemic and the resulting global health and economic emergency. The pandemic is profoundly affecting the lives of persons living with disabilities across the life course, and in all aspects of employment [4, 14]. The effects of the pandemic are particularly hurtful to individuals who are living in, or perilously close to, poverty; who have multiple, intersectional minority identities associated with race, ethnicity, sexual orientation, and gender identity; who are addressing the limits of age; or who are facing the many and varied challenges of disability otherwise or in conjunction with other life and family experiences such as ableism, racism, and sexism.

My 2020 book, Disability Law and Policy [1], examines the ADA at its thirtieth year, but it was mostly written during the years immediately preceding the pandemic. Prior to the pandemic, by most estimates, there were 60 million individuals (almost one in five) in the USA living with disabilities. Before the emergency, more than one-quarter of the working-age people with disabilities in the United States were living below the poverty level, over twice the rate of those without disabilities [1]. Despite modest declines in unemployment rates during the years immediately preceding the pandemic, people with disabilities were still disproportionately excluded from the labor market and from other economic, social, and civic opportunities [15-18]. During the pandemic, people with disabilities are being even further left out of the labor market $[11,19,20]$.

My 2022 book, Advanced Introduction to Disability Law [21], is being written during the throes of the pandemic. It considers how, during the health and economic emergency, the persistent exclusion of persons with disabilities from the labor market has significantly worsened. This situation is dire, despite the United States having reached the fourth decade since the ADA's enactment, and despite the disability model based on civil rights ("Rights Model") that began to influence U.S. government policy as far back as the 1970s. This Rights Model and the parallel "Social" (or Ecological) Model view persons with disabilities as a minority group, entitled to the same hard-won legal protections for equality that have emerged from the struggles of African Americans, women, older adults, and individuals with differing sexual orientations and gender identities [1].

The recognition that people with disabilities have rights in American law, rather than being people who must somehow "overcome" their different personal traits to participate in society, is the central insight of the ADA; that is, "disability" is merely a social construct, the result of the interaction between a person with an impairment and the "able"oriented society in which the person lives. In the past, U.S. laws, policies, and practices had subordinated the rights of people with disabilities [22]. With the ADA, the government aimed to secure the equality of people with disabilities by eliminating barriers that unfairly preclude full and equal involvement in society.

This special section of the Journal of Cancer Survivorship examines disability-inclusive employment policy and practice, cancer survivorship, and the ADA [1]. It considers current issues in research, practice, and law in the United States, especially new questions that have arisen because of COVID-19. Matters discussed include the nature of disability disclosure, workplace accommodations and remote work, emerging workplace health surveillance technologies, and inclusive employment practices for cancer survivors and for others with disabilities [23]. It also presents, for comparative purposes, an analysis of cancer-related disability discrimination in the media in the United States and Israel.

After this "Introduction," the articles in this special section consider a range of topics. Beginning with two studies on the disclosure of disability, and cancer in particular, the first two articles examine the process of raising the need for workplace accommodations, the first during job interviews, and the second, thereafter (as affected by individual and organizational characteristics). The next two articles study the implications of the pandemic for working people with disabilities and cancer survivors, first for those working remotely, and then, for those working and applying for work subject to pandemic-enhanced workplace health surveillance and algorithmic health discrimination. The final article considers cancer-related stigma and discrimination in the United States and Israel, using a comparison of mass media. Taken together, the articles in this special section consider, variously, the future of disability-inclusive 
employment from research, policy, practice, and comparative perspectives.

\section{Disability-inclusive employment for people with disabilities}

The disability-inclusive employment paradigm is a concept of the late twentieth century. It contrasts with earlier vocational rehabilitation programs for people with disabilities that were based on medicalized conceptions of disability $[1,22]$. The historically dominant "Medical Model" of disability focused on individual deficits, with impairments conceived of as infirmities that precluded participation in the mainstream economy [24, 25]. It cast people with disabilities in a subordinate role to doctors, rehabilitation professionals, and governmental bureaucrats, each of whom aimed to "help them," when "deserving," adjust to a society structured around the convenience, design, and interests of people without disabilities [22, 26-28].

The modern Social Model of disability, sometimes called the Ecological Model, and, in the context of the ADA, the Disability Civil Rights Model, has changed society's perspective. It has altered the historical paradigm from a focus on an "other" health status, to be cured or rehabilitated, and even pitied, towards acceptance of individual differences, to be accommodated within reason, in employment and generally in society, as a natural part of the human experience.

\section{Rehabilitation research and training centers on disability-inclusive employment}

The pandemic has brought to the fore the need for fresh development of a robust literature, science, and practice on disability-inclusive employment policy for people with disabilities and for cancer survivors. In this regard, two new 5-year and complementary national Rehabilitation Research and Training Centers, one on Disability Inclusive Employment Policy ("DIEP RRTC") and one on Employer Practices Leading to Successful Employment Outcomes Among People with Disabilities ("Employer Practices RRTC"), are introduced just below. Together, they are designed to contribute to a body of study and to examine ways in which organizations, including those engaged in the online gig economy, can facilitate the inclusive employment of people with disabilities.

The new 5-year DIEP RRTC is implementing a series of empirical studies to produce data and evidence showing how to increase employment opportunity for people with disabilities [4]. It is examining how organizations of all sizes and types, including those in the gig economy, facilitate the inclusive employment of people with disabilities. Particularly in light of the profound changes to employment and society generally brought on by the pandemic, it is crucial to examine ways in which organizational and individual work strategies evolve, incorporate, and sustain inclusive disability employment policy and practice.

The DIEP RRTC brings together a consortium of recognized and synergized researchers from disciplines including disability studies, economics, psychology, social work, law, public policy, business, and health policy. The Center's team is comprised of, and directed by, leading members of the disability community. It is complemented by national associations providing unprecedented reach to targeted audiences for knowledge dissemination activities.

Among its activities, the DIEP RRTC is undertaking a scientifically rigorous set of randomized control trial ("RCT") and quasi-experimental studies on the employment lifecycle of people with disabilities. These studies examine ways to enhance employment engagement, re-engagement, and new forms of work, as well as job quality and retention. They examine federal, regional, state, local, and privateindustry policies and programs to identify outcomes that improve employment entry options, wage and income levels, worker accommodation and retention, job quality and benefits, career growth and paths to economic stability, and employment re-engagement in the event of job loss-outcomes that can also reduce dependence on governmental Social Security disability benefits.

The DIEP RRTC's objectives are to provide policy makers and employers evidence-based options for employment policy and practice, vocational rehabilitation programs, and workforce development. It aims to increase strategies to support job seekers with disabilities, and the businesses and human resource professionals who hire them, by identifying evidence-based practices that enhance worker retention and the quality of the work experience.

The corresponding objective of the new 5-year Employer Practices RRTC is to produce scientifically rigorous and scalable evidence to meaningfully increase the employment of persons with disabilities [14]. This endeavor also brings unprecedented partnerships with leading universities and prominent disability organizations, in collaboration with major companies and smaller businesses across market and labor sectors.

This Employment Practice RRTC will implement a series of studies, again using quasi-experimental and RCT studies, to provide valid, reliable, and scalable metrics as to employment practices for persons with disabilities across the employment lifecycle. The focus is on the post-pandemic "new norm" practices facing businesses, and their job applicants and new hires, in retaining, advancing, and accommodating employees with disabilities.

The Employment Practices RRTC has three related project streams: (1) quasi-experimental evidence of best practices across the employment life cycle from committed major companies and smaller businesses; (2) RCT evidence 
of the effects of different practices on trust and self-disclosure among job applicants and current employees, and of the effects of accommodations for individuals with less visible disabilities, such as mental health, cognitive, and other health conditions such as cancer; and (3) the effects of best practices on smaller and non-traditional employers, and on healthcare workers.

The projects in both RRTCs are among the first to use and integrate quasi-experimental and RCT studies to identify, examine, and measurably increase employer practices that promote workplace climates of inclusion, employeeemployer trust, and positive employment outcomes, among other core outcomes. Both RRTCs are spearheading focused studies of people with disabilities using an intersectional lens, with inclusion of individuals with disabilities who have multiple minority identities along race, ethnicity, gender identity and sexual orientation, and age vectors. Their findings will provide access to practical and effective information, along with the knowledge translation needed so diverse individuals across the spectrum of disabilities and their employers can implement practices and explore innovative paths to improved employment experiences and career advancement.

Both RRTCs plan studies on ways to guide post-pandemic "new norm" employer practices to improve the employment status of people with disabilities. The combined programs of research constitute a major leap forward in the analysis of disability-inclusive employment practices. The data will provide a robust basis for understanding which practices actually promote disability-inclusive employment outcomes for people with disabilities.

Both RRTCs also aim, over the longer term, to provide evidence to support existing and next-generation research. They will disseminate information widely to target audiences in employment policy briefs, academic articles, and academic presentations. Online and in-person training and technical assistance support will be provided for policymakers, business leaders, and people with disabilities. Trainings and continuing education for vocational rehabilitation and workforce development professionals, along with webinars and virtual academies, will bring together key stakeholders for collective learning and action.

\section{ADA employment discrimination and cancer}

Despite the ambitious RRTC programs underway examining disability-inclusive employment, it is important to recognize the pernicious nature of the historic and continuing employment discrimination faced by individuals with cancer. Today, employers and co-workers still harbor misperceptions and biases about an individual's ability to work during and after undergoing treatment for cancer.
About one-quarter of individuals with cancer report some form of discrimination in the workplace despite protections from discrimination under the ADA [23]. Currently, individuals with chronic health conditions such as cancer assert among the highest rates of ADA complaints regarding the failure to make reasonable accommodations in the workplace [29]. Cancer survivors also experience unique attitudinal and structural bias in the workplace, and in the media [30], as compared to individuals with other disabilities [31].

Cancer survivors thus face distinctive workplace challenges. People who continue to work during cancer treatment often must overcome fatigue, nausea, and other side effects of treatment. Fear of being fired or being repositioned to a lower status job, however, may compel them to continue working but to be hesitant to seek needed accommodations by disclosing their situation.

A supportive work environment and culture tend to facilitate the return to work, while manual work and settings that require physical effort represent impediments $[18,19$, 32-35]. The positive attitudes of employers and colleagues, and approval of flexible work hours and remote work as accommodations, are important elements of a disabilityinclusive work environment $[5,6,11]$. However, many people with cancer still experience non-inclusive work environments and face attitudinal discrimination. Some assert their rights under the ADA and other laws to rectify this situation.

\section{ADA Title I}

Title I of the ADA covers employment. It mandates that no covered entity shall discriminate against a qualified individual with a disability in job application procedures, hiring, advancement, discharge, compensation, job training, and other terms of employment [1]. Employers are provided a defense to a discrimination claim where accommodating the employee's needs would constitute "undue hardship" for the employer or where an employee poses a significant risk to the health or safety of herself or others in the workplace; this latter aspect has become a point of debate during the pandemic.

Under the ADA, "discrimination" includes failure to make reasonable accommodations to the physical and mental limitations of a qualified individual with a disability, in the absence of an undue hardship on the business [1]. Discrimination includes denying opportunities to a job applicant or employee if the denial is based on a disclosed need for reasonable accommodations to that person's physical or mental conditions [1, 36, 37]. By directing employers to accept responsibility for accommodations, within reason (up to the undue hardship ceiling), the ADA is distinct from other U.S. civil rights legislation.

A cancer diagnosis, as with any impairment or illness, is not per se a disability covered by the ADA. Instead, to 
determine if a condition is a disability as defined by the ADA, courts analyze each claim on case-by-case basis. A condition, such as cancer, will be considered a disability under the ADA when its effects, or the side effects of treatment, substantially limit one or more "major life activities" [33]. For instance, if depression resulting from cancer substantially limits a person's sleeping or eating for an extended period, the cancer may be considered a disability. Cancer may also be considered a disability if it substantially limited the employee in the past, or if the employer incorrectly regards the employee as having a substantial limitation.

\section{Recent ADA case law examples}

Despite the many challenges of cancer, cancer treatment, and pre-cancerous conditions, establishing one of these statuses as a disability can be a challenging and long-term process. In Darby v. Childvine, Inc. [38], for example, decided in 2020, the plaintiff had a double mastectomy after being diagnosed as having pre-cancerous cells associated with a genetic mutation (BRCA1) that contributes to abnormal cell growth. She alleged that she was discriminated against under the ADA when her employer terminated her employment upon learning of her condition. The question facing the court was whether to dismiss Darby's claim that her genetic mutation, with the associated growth of abnormal cells, constituted a disability under the ADA. The court held that Darby had plausibly alleged that her impairment substantially limited a major life activity—her normal cell growth—since the condition was serious enough to warrant a double mastectomy.

Years earlier, in the first ADA case decided by United States Supreme Court, Bragdon v. Abbott [39], the Court had held that infection with the HIV virus, even in the absence of symptoms of AIDS, was a disability covered by the ADA. But the decision was based on the virus's immediate effect on bodily functions, not because of the potential for it to lead to AIDS. In Darby, similarly, the court held that a genetic mutation (or other physical characteristic) that only predisposed an individual to other possible health conditions, in this case breast cancer, would not itself be a disability under the ADA.

The court left it to further proceedings to determine if Darby could go beyond allegations to prove that her condition in fact substantially limited normal cell growth over time. If not, her claim will fail because short-term temporary impairments, without serious or long-term effects, are not likely to be considered "substantial" impairments or conditions under the ADA. Under the ADA's "regarded as" prong of disability, transitory (expected duration of less than 6 months) and minor impairments are not covered by the law (e.g., Eshleman v. Patrick Industries, Inc [40]).

The story of Patricia Garrett, a nurse working for the University of Alabama at Birmingham hospital, involved a 13-year legal saga in which federal law and its courts failed an individual with cancer who had been subjected to discrimination on the basis of her illness [41]. Ms. Garrett was a supervising nurse at the state-run University hospital when, in August 1994, she was diagnosed with breast cancer. She took time off for a series of treatments and returned to work full-time in September of that year. Due to her ongoing treatments, Ms. Garrett requested and received intermittent medical leave over the next year.

At work, Ms. Garrett was able to complete her job duties with accommodation. However, radiation therapy caused burns to her right arm that limited her lifting ability. She needed extra time and had to take frequent work breaks due to fatigue. At times, she was hospitalized for an infection, took medical leave as an accommodation, and then returned to work. Soon after one return to work, she was transferred to a lower-paying position at a different University facility.

The question in Garrett was whether an individual employed by a state may recover money damages from the state under the ADA's employment discrimination provisions. In Board of Trustees of University of Alabama v. Garrett, the Supreme Court held that such suits were barred by the Eleventh Amendment to the U.S. Constitution [41]. In so many words, the Garrett Court held that Congress had not found a sufficient pattern of unconstitutional discrimination against people with disabilities, cancer in this case, in state employment.

But Garrett, seemingly, was not left without the possibility of legal relief. On remand, the U.S. Court of Appeals for the Eleventh Circuit held that Garrett could sue the State of Alabama for monetary damages under the Rehabilitation Act of 1973 (a sister disability antidiscrimination law to the ADA). The court held that the state, and by implication its agencies, had waived sovereign immunity by accepting federal funds. Nevertheless, on remand to the lower District Court, that court held Garrett was not a qualified individual with a disability for purposes of the Rehabilitation Act (which uses the same definition in this situation as the ADA), and her case was dismissed.

Depending on the individual circumstances, a COVID-19 infection might be considered an ADA disability, particularly if serious associated conditions and symptoms result, even when they last less than six months. In Fraihat v. U.S. Immigration and Customs Enforcement, the court noted that cancer is among the health conditions that place people at a at heightened risk of severe illness and death upon contracting COVID-19 [42]. In Busby v. Bonner, the court cited the $\mathrm{CDC}$ recognition that cancer treatment can cause a person to be immunocompromised and hence potentially vulnerable to COVID-19 infection [43]. At some lower level of seriousness, however, a COVID-19 infection would probably be considered a transitory and minor condition not covered by the Act. 
How far do Title I's protections reach? In 2020, the United States Supreme Court ruled that the First Amendment-which includes the right of religious institutions to be free from state interference-permits courts to dismiss ADA Title I claims involving teachers at religious schools. In St. James School v. Biel, a case consolidated with Our Lady of Guadalupe School v. Morrissey-Berru and addressed under the latter case name [44], Ms. Biel worked as a lay teacher at a Catholic school. After the school did not renew Biel's contract, she alleged under the ADA that she had been discharged because she had requested an accommodation leave for breast cancer treatment. The school maintained its decision was based on her poor performance.

The Supreme Court ruled that the First Amendment's Religion Clauses prevented Biel's Title I claim. Relying on a similar ADA case brought 8 years earlier, Hosanna-Tabor Evangelical Lutheran Church and School v. EEOC [45], the Court ruled the First Amendment barred the Title I discrimination claim on the basis of a "ministerial exception" to the ADA. The ADA does permit religious institutions to consider religion when making employment decisions, and they may require that job applicants and employees conform to their religious tenets.

The broadly interpreted ministerial exception bars otherwise qualified individuals with disabilities such as cancer or diabetes from ADA Title I coverage when they are employed by religious institutions. Religious organizations are thus able to direct and control their employees without coverage by employment discrimination statutes like the ADA in areas such as hiring, firing, promotion, compensation, and benefits. In 2021, using similar reasoning, the Seventh Circuit held in Demkovich v. St. Andrew the Apostle Parish that workplace harassment and intimidation on the basis of cancer or other disabilities, even when it is severe, creates an abusive working environment, and is not related to the conditions of employment, is still protected by the ministerial exception [46].

Contributions to this special section.

This special section presents transdisciplinary perspectives from American and comparative research, law, and policy regarding the future of disability-inclusive employment, with a special focus on employment issues faced by cancer survivors. The articles consider the "new norms" in employment as relevant to workplace accommodations, such as flexible workhours, remote work, and reasonable adjustments to the ways work is performed, with a focus on enabling productive participation in the economic mainstream during and after the pandemic and across the spectrum of disabilities, including cancer survivorship.

The articles address traditional employer-employee relationships and the relationships developed when people with disabilities choose to create flexible work arrangements that they own and operate, as self- and independent-contractors do. The flexibility of such arrangements is one reason that a relatively high proportion of people with disabilities engage in self-employment in the new "gig" economy rather than pursuing traditional employment [33, 34].

Two empirical investigations of disability disclosure in employment, including cancer survivorship, are initially presented: First, disclosure when raising the need for accommodations in job interviews and, second, disclosure as related to individual and organizational characteristics. The next two articles study, respectively, the effects of the pandemic on people with disabilities, including cancer survivors, who are working remotely, and the discriminatory effects of COVID19-related increases in workplace health surveillance and algorithmic health discrimination on cancer survivors and others with disabilities. The final article considers current cancer-related stigma and discrimination in the United States and Israel, using a comparative lens.

In the first article, Ameri and Kurtzberg examine the job interview process for those living with chronic pain, a frequent complication of cancer and its treatments, who need disability accommodations on the job, and whether disclosing this information early in the interview process is related to hiring outcomes [47]. The experimental design addressed both the effects of using different means of communicating the information, and the effects of the timing of the disclosure, to offer suggestions for negotiation strategy. Early disclosure of the need for accommodations was associated with poorer ratings of employability, as was late disclosure. Disclosure via audio was damaging, whether it occurred early or late. Asking for a significant increase in salary close in time to disclosure was also problematic.

The study results demonstrate that salary requests are sensitive topics that can be negatively affected by poor timing or means of disclosure. Ameri and Kurtzberg suggest that holding off on disclosure and the request for accommodations until later in the job interview, when a good impression has been established, enhances hiring possibilities [19]. Difficult disclosures are better received using combined audio and video communication channels. The implications for cancer survivors are that if accommodations are needed on the job, waiting until later in the job interview to discuss this topic, using video and audio communications, and ensuring distance in time from making a salary request, can be effective approaches.

Offering a perspective from the other side of the workplace setting, Hyseni, Myderrizi, and Blanck next examine lawyers' reports of their personal openness to disclosing their own cancer and other disabilities at their places of employment [36]. This article is a companion article to others based on a large, ongoing investigation involving 3500 lawyers across the country with disabilities and other intersectional background identities [48-50]. This particular article examines factors that determine, for lawyers with less 
visible disabilities, such as mental illness, and chronic health conditions, such as cancer, when they are open to disclosure of such identities. The authors investigate the associated role of individual characteristics and their intersection, including disability, sexual orientation, gender identity, race, ethnicity, and age.

Hyseni and colleagues find that openness to disclosing disability varies based on disability-related factors (onset, visibility, type), and type of workplace accommodation requests. Other identity factors such as gender, sexual orientation, age, and having children can help explain differences in willingness to disclose. Job-related factors such longer tenure, a smaller size of venue, and an inclusive workplace are associated with increased willingness to disclose.

The findings affirm existing evidence on the relationship between visibility of disability and workplace disclosure suggesting that individuals with more visible disabilities are more likely to disclose. The implications for cancer survivors are that people with health conditions such as cancer that are often acquired later in life are less likely to disclose these conditions in their workplaces. The relevance of the findings is heightened by the altered work conditions and demands imposed by the COVID-19 pandemic for cancer survivors and others with disabilities.

Kruse, Park, Rogers, and Schur then examine disability and remote work during the pandemic, with implications for cancer survivors [37]. Using recent data on COVID-19 from the Current Population Survey over the May 2020 to June 2021 period, they examine the extent to which employees were working from home because of the pandemic, focusing on differentials between people with and without disabilities. They present descriptive statistics and the results from regression and decomposition analysis.

Kruse and colleagues find that while workers with disabilities were more likely than those without disabilities to be teleworking before the pandemic, they were less likely to be teleworking because of the pandemic. Differences in the occupational distribution account for most of this difference. Thus, although people with disabilities may benefit from working at home, and the pandemic has increased employer acceptance of these arrangements, the potential is limited by current occupational distribution. Kruse and colleagues draw on other data to estimate that people with disabilities, as measured in the CPS, are twice as likely as people without disabilities to be cancer survivors, so the results have strong relevance for cancer survivors.

Harpur, Hyseni, and Blanck next examine an area, COVID-19 regulatory interventions, that has created new and unprecedented grounds for exclusion and has intensified inequalities facing marginalized individuals such as people with disabilities [44]. The regulations require employers to play a major role in ensuring the health and safety of their workers and the public. But the use of algorithmic (or automatic) decision-making ("ADM") data gathered as part of COVID-19 public health surveillance is having profound and lasting impacts on equal participation in society for marginalized groups with disabilities.

Harpur and colleagues contend that while the emerging COVID-19 health surveillance technologies have helped control the spread of the pandemic, they pit health and safety concerns against individual privacy and can thereby result in discrimination. The interaction between ADM and COVID19 health surveillance in the workplace has increased employers' capacity to detect people with disclosed and undisclosed health (and often not visible) concerns, such as cancer. The broadened surveillance abilities have created a new class of people who will potentially experience employment inequalities - algorithmic health discrimination ("AHD")—-due to the pandemic [35, 51].

Lastly, Soffer considers cancer-related stigma and discrimination in the United States and Israel via an exploratory study of mass media [30]. Her starting points are that cancer is a stigmatized condition in many cultures and that a culture's mass media is a key component in producing illness-related structural stigma. Through a thematic analysis of published media articles mentioning cancer, Soffer examines the social construction of cancer-related stigma in mass media through a comparison of how the stigma was constructed over a recent period in the American and Israeli mass media.

Soffer's comparative analysis finds parallel themes, such as the marginalization of cancer, cancer as metaphor, and the war against cancer. In both samples, people with cancer were depicted as heroic. While some themes differed across sociocultural dimensions, Soffer concludes that there appear to be both universal and culturally specific representations of cancer-related stigma in the media $[17,25]$. The findings illustrate the importance of exposing cancer-related stigma in the media and elsewhere, and of developing culturally informed guidelines for reporting about cancer, with meaningful support from and collaboration with cancer survivors and their families, reporters, and other stakeholders $[52,53]$.

\section{Conclusion}

Disability-inclusive employment has taken on exceptional importance due to the health, social, and economic emergency arising from the global pandemic [19, 20, 37, 54]. The pandemic is challenging public and private entities in unprecedented ways, and it has spurred traditional and new forms of employment and economic opportunity. But people with disabilities are currently experiencing among the highest rates of job loss, as compared to those without disabilities, from the pandemic emergency [48, 49]. 
Exacerbating the problem, people with disabilities often identify with other and multiple minority identities that are themselves marginalized in society. They may also be women, people of color, and individuals identifying with different sexual orientations and gender identities [24, 25, 29, 36]. Disability diversity, equity, and inclusion ("DEI") programs that incorporate the accommodation principle for all identities - what my colleagues and I call "DEI+"-are crucial to people with disabilities who seek to enter or re-enter the mainstream economy.

It is apparent that the use of overly broad terms such as "cancer," "disability," "LGBTQ +," and "racial/ethnic minority" do not adequately acknowledge the unique individual and multiple identities, all often associated with prior inequality and oppression, that exist across and within these individual categories of convenience. The same lack of nuance is found in reports of individual "discrimination" and "bias." These labeling schemes are a place to start, but they are overly simplistic, as is the term cancer itself.

No study released during this era can ignore the ways in which the pandemic is changing our life experiences, and rarely for the better [55]. Future studies will need to look closely, among other things, at how the pandemic has affected the lives of many individuals who had already struggled with stress and discrimination related to the rising prevalence of mental health issues of various kinds. Future efforts must consider, over time, how identity disclosure and stigma, reported discrimination and bias, and the use of health surveillance technologies play out in the workplace for cancer survivors and others with disabilities. The longer-term objective is to mitigate bias and discrimination facing persons with minority identities and to further a culture of DEI + in the workplace.

The leading-edge research, policy, and practice paradigms discussed by the authors in this special section will, we hope, positively affect organizational culture and individual views and outcomes, all in ways that foster full and equal opportunity, and self-empowerment, for cancer survivors and others $[4,14,18,37,56-59]$. At the thirty-second anniversary of the ADA, these endeavors are more important than ever to further organizational DEI+ efforts [60].

Acknowledgements I thank Mary Trevor for her comments on a prior version of this article.

Funding This line of study was supported in part by grants to Syracuse University, Peter Blanck (Principal Investigator), from the National Institute on Disability, Independent Living, and Rehabilitation Research (NIDILRR) for: the Rehabilitation Research \& Training (RRTC) on Employment Policy: Center for Disability-Inclusive Employment Policy Research, Grant \#90RTEM0006-01-00; the Southeast ADA Center, Grant \#90DP0090-01-00 and 90DPAD000501-00; Increasing Supported Decision Making in Community Living, Grant \#90DP0076-01-00; and, sub-grants to Syracuse University, Peter Blanck (PI), for the ADA-PARC, Lex Frieden PI, Grant \#H133A12000, and the RRTC on Employer Practices Leading to Successful Employment Outcomes Among People with Disabilities, Douglas Kruse PI, Grant Application \#RTEM21000058. NIDILRR is a Center within the Administration for Community Living (ACL), Department of Health and Human Services (HHS). The views provided herein do not necessarily reflect the official policies of NIDILRR nor do they imply endorsement by the Federal Government.

\section{Declarations}

Consent for publication Author Peter Blanck consents to publication of this material.

Conflict of interest The author declares no conflict of interest.

\section{References}

1. Blanck P. Disability law and policy. St. Paul MN: Foundation Press; 2020.

2. Blanck P. Why America is better off because of the Americans with Disabilities Act and the Individuals with Disabilities Education Act. Touro Law Rev. 2019;35:605-18.

3. Blanck P. On the importance of the Americans with Disabilities Act at thirty. J Disabil Policy Studs. 2021. https://doi.org/10.1177/ 10442073211036900.

4. Blanck P [Principal investigator]. Rehabilitation Research Training Center on Disability Inclusive Employment Policy, funded by the U.S. National Institute on Disability, Independent Living, and Rehabilitation Research (NIDILRR). 2020.

5. Blanck P. Disability inclusive employment and the accommodation principle: emerging issues in research, policy, and law. J Occup Rehabilit. 2020;30:505-10.

6. Schur L, Nishii L, Adya M, Kruse D, Bruyère SM, Blanck P. Accommodating employees with and without disabilities. Hum Resours Manag. 2014;53(4):593-621.

7. Blanck P. The economics of the employment provisions of the Americans with Disabilities Act: Part I-Workplace accommodations. DePaul Law Rev. 1997;46(4):877-914.

8. Schartz H, Schartz K, Hendricks DJ, Blanck P. Workplace accommodations: empirical study of current employees. Miss Law J. 2006;75:917-43.

9. Schartz H, Hendricks DJ, Blanck P. Workplace accommodations: evidence-based outcomes. Work. 2006;27:345-54.

10. Stein M, Silvers A, Areheart BA, Francis L. Accommodating every body. Univ Chic Law Rev. 2014;81(2):689-756.

11. Schur L, Kruse D, Blasi J, Blanck P. Is disability disabling in all workplaces? Disability, workplace disparities, and corporate culture. Ind Relats. 2009;48(3):381-410.

12. Maestas N, Mullen KJ, Rennane S. Unmet need for workplace accommodation. J Policy Anal Manag. 2019;38(4):1004-27.

13. Zwerling C, Whitten PS, Sprince NL, Davis CS, Wallace RB, Blanck P, et al. Workplace accommodations for people with disabilities: national health interview survey disability supplement, 1994-1995. J Occup Environ Med. 2003;45(5):517-25.

14. Kruse D [Principal investigator], Blanck P [Co-Principal Investigator]. Rehabilitation Research Training Center on employer practices leading to successful employment outcomes among people with disabilities, funded by the U.S. National Institute on Disability, Independent Living, and Rehabilitation Research (NIDILRR). 2021. 
15. Ali M, Schur L, Blanck P. What types of jobs do people with disabilities want? J Occup Rehabilit. 2011;21(2):199-210.

16. Blanck P. eQuality: The struggle for web accessibility by persons with cognitive disabilities. NY: Cambridge University Press; 2014.

17. Blanck P. The first "A" in the ADA: and 25 more "A"s toward equality for Americans with Disabilities. Inclusion. 2016;4(1):46-51.

18. Morris M, Goodman N, Baker A, Palmore K, Blanck P. Closing the disability gap: reforming the Community Reinvestment Act regulatory framework. Georget J on Poverty Law \& Policy. 2019;XXVI(3):347-74.

19. Schur L, Ameri M, Kruse D. Telework after COVID: a "silver lining" for workers with disabilities? J Occup Rehabilit. 2020;30:521-36.

20. Schur L, van der Meulen Y, Kruse D. COVID-19 and employment losses for workers with disabilities: an intersectional approach. Handbook of Disability and Management; forthcoming.

21. Blanck P. Advanced introduction to disability law. 2022; Cheltenham UK, Elgar Publishing; forthcoming.

22. Logue L, Blanck P. Before the accommodation principle: disability and employment among Union Army veterans. J Occup Rehabilit. 2020;30:565-74.

23. Blanck P, Myhill W, Solstad Vedeler J, Morales J, Pearlman P. Individuals with cancer in the workforce and their federal rights. In: Feuerstein M, editor. Work and Cancer Survivors. NY: Springer; 2009. pp. 255-76.

24. Blanck P, Millender M. Before civil rights: civil war pensions and the politics of disability in America. Ala Law Rev. 2000;52:1-50.

25. Blanck P. Civil War pensions and disability. Ohio State Law J. 2001;62:109-249.

26. Logue L, Blanck P. Heavy laden: Union veterans, psychological illness, and suicide. NY: Cambridge University Press; 2018.

27. Logue L, Blanck P. Race, ethnicity, and disability: veterans and benefits in post-Civil War America. NY: Cambridge University Press; 2010.

28. Logue L, Blanck P. "Benefit of the doubt": African-American Civil War veterans and pensions. J Interdiscip Hist. 2008;xxxviii(3):377-99.

29. Strauser D, Leslie M, Rumrill P, McMahon B, Greco C. The employment discrimination experiences of younger and older Americans with cancer under Title I of the Americans with Disabilities Act. J Cancer Survivorship. 2020;14:614-62.

30. Soffer M. Cancer-related stigma in the U.S. and Israeli mass media: an exploratory study of structural stigma. J Cancer Survivorship. 2021; : _- -

31. Leslie M, Strauser D, McMahon B, Greco C, Rumrill P. The workplace discrimination experiences of individuals with cancer in the Americans with Disabilities Act Amendments Act era. J Cancer Survivorship. 2020;30:115-24.

32. Blanck P. Supported decision-making: emerging paradigm in research, law, and policy. J Disabil Policy Studs. 2021. https:// doi.org/10.1177/10442073211023168.

33. Ostrow L, Smith C, Nemec PB. Self-employment for people with psychiatric disabilities: advantages and strategies. J Behav Health Servs \& Res. 2019;46:686-96.

34. Ostrow L, Smith C, Penney D, Shumway M. "It suits my needs": self-employed individuals with psychiatric disabilities and small businesses. Psychiatr Rehabilit J. 2018;42(2):121-31.

35. Harpur P, Blanck P. Gig workers with disabilities: opportunities, challenges, and regulatory response. J Occup Rehabilit. 2020;30:511-20.

36. Hyseni F, Myderrizi A, Blanck P. Diversity and inclusion in the legal profession: disclosure by lawyers with disabilities and lawyers who identify as LGBTQ+. J Cancer Survivorship. 2021; : - . .

37. Kruse D, Park SR, Rodgers Y, Schur L. Disability and remote work during the pandemic with implications for cancer survivors. J Cancer Survivorship. 2021;

38. Darby v. Childvine, Inc., 964 F.3d 440 (6th Cir. 2020).

39. Bragdon v. Abbott, 524 U.S. 624 (1998).

40. Eshleman v. Patrick Indus, Inc., 961 F.3d 242 (3d Cir. 2020).

41. Board of Trustees of Univ Ala v. Garrett, 531 U.S. 356 (2001).

42. Fraihat v. U.S. Immigr and Custs Enforc, 445 F. Supp. 3d 709 (Cent. Dist. Calif. 2020).

43. Busby v. Bonner, 466 F. Supp. 3d 821 (West. Dist. Tenn. 2020).

44. Our Lady of Guadalupe Sch. v. Morrissey-Berru, St. James Sch. v. Biel, 140 S. Ct. 2049 (2020).

45. Hosanna-Tabor Evangelical Lutheran Church \& Sch. v. EEOC, 565 U.S. 171 (2012).

46. Demkovich v. St. Andrew the Apostle Parish, 3 F.4th 968 (7th Cir. 2021) (en banc)

47. Ameri M, Kurtzberg T. The disclosure dilemma: requesting accommodations for chronic pain in job interviews. J Cancer Survivorship. 2021;____-_.

48. Blanck P, Hyseni F, Altunkol WF. Diversity and inclusion in the legal profession: preliminary findings on workplace accommodations from a national study of lawyers with disabilities. J Occup Rehabilit. 2020;30:537-64.

49. Blanck P, Abdul-Malak Y, Adya M, Hyseni F, Killeen M, Wise FA. Diversity and inclusion in the American legal profession: first phase findings from a national study of lawyers with disabilities and lawyers who identify as LGBTQ+. Univ DC Law Rev. 2020;23:23-87.

50. Blanck P, Hyseni F, Altunkol WF. Diversity and inclusion in the legal profession: discrimination and bias reported in a national study of lawyers with disabilities and lawyers who identify as LGBTQ+. Am J Law \& Med. 2021;46(4):21-63.

51. Harpur P, Connolly U, Blanck P. Hierarchies of impairments at work in Australian and Irish workers' access to compensation for injuries. J Occup Rehabilit. 2017;27(4):507-19.

52. Logue L, Blanck P. Civil War veterans, physicians, and cancer. Burton Blatt Institute Working Papers; 2021 (available from authors).

53. Shogren K, Wehmeyer M, Martinis J, Blanck P. Supported decisionmaking: theory, research, and practice to enhance self-determination and quality of life. NY: Cambridge University Press; 2019.

54. Harpur P, Hyseni F, Blanck P. Workplace COVID-19 health surveillance and algorithmic disability discrimination. J Cancer Survivorship. 2021;

55. Bryant M, Knox S. Cancer in the time of COVID. Health Lawyer. 2021;33(3):39-49.

56. Blanck P. Thirty years of the Americans with Disabilities Act: law students and lawyers as plaintiffs and advocates NY Univ Rev. Law \& Soc Change. 2021;45:8-24.

57. Blanck P, Martinis J. "The Right to Make Choices": National Resource Center for Supported Decision-Making. Inclusion. 2015;3(1):24-33.

58. Blinder V, Gany F. Impact of cancer on employment. J Clin Oncol. 2020;38(4):302-9.

59. Morrison C. Don't let the shift to remote work sabotage your inclusion initiatives. In: The i4cp Ppoductivity blog. 2020. https:// www.i4cp.com/coronavirus/dont-let-the-shift-to-remote-worksabotage-your-inclusion-initiatives? referringSource $=$ articleSha re. Accessed 14 Oct. 2020

60. Schur L, Kruse D, Blanck P. People with disabilities: sidelined or mainstreamed? NY: Cambridge University Press; 2013.

Publisher's note Springer Nature remains neutral with regard to jurisdictional claims in published maps and institutional affiliations. 


\section{Authors and Affiliations}

\section{Peter Blanck ${ }^{1}$ (D)}

$\triangle$ Peter Blanck

pblanck@syr.edu

Burton Blatt Institute, Syracuse University, 950 Irving Avenue, Suite 446, Syracuse, NY 13244, USA 